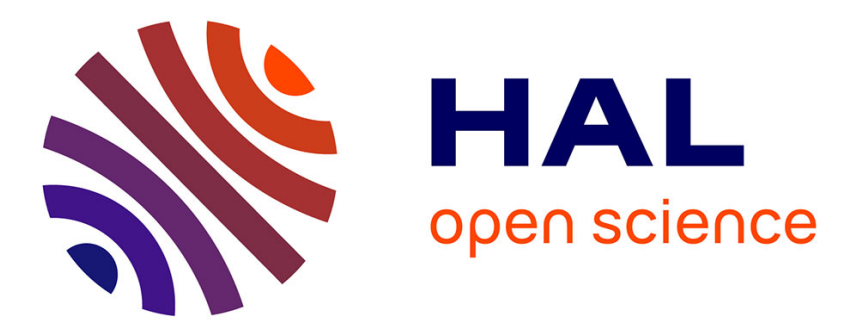

\title{
Development of Nafion/Tin Oxide Composite MEA for DMFC applications
}

Fang Chen, Barbara Mecheri, Alessandra d'Epifanio, Enrico Traversa, Silvia Licoccia

\section{> To cite this version:}

Fang Chen, Barbara Mecheri, Alessandra d'Epifanio, Enrico Traversa, Silvia Licoccia. Development of Nafion/Tin Oxide Composite MEA for DMFC applications. Fuel Cells, 2010, 10 (5), pp.790. 10.1002/fuce.200900179 . hal-00578451

\section{HAL Id: hal-00578451 https://hal.science/hal-00578451}

Submitted on 21 Mar 2011

HAL is a multi-disciplinary open access archive for the deposit and dissemination of scientific research documents, whether they are published or not. The documents may come from teaching and research institutions in France or abroad, or from public or private research centers.
L'archive ouverte pluridisciplinaire HAL, est destinée au dépôt et à la diffusion de documents scientifiques de niveau recherche, publiés ou non, émanant des établissements d'enseignement et de recherche français ou étrangers, des laboratoires publics ou privés. 


\section{Development of Nafion/Tin Oxide Composite MEA for DMFC applications}

\begin{tabular}{|r|l|}
\hline Journal: & Fuel Cells \\
\hline Manuscript ID: & fuce.200900179.R2 \\
\hline Wiley - Manuscript type: & Original Research Paper \\
\hline Date Submitted by the & 19 -Apr-2010 \\
\hline Complete List of Authors: & $\begin{array}{l}\text { Chen, Fang; University of Rome Tor Vergata, Department of } \\
\text { Chemical Science and Technology } \\
\text { Mecheri, Barbara; University of Rome Tor Vergata, Department of } \\
\text { Chemical Science and Technology } \\
\text { D'Epifanio, Alessandra; University of Rome, Chemical Science and } \\
\text { Technology } \\
\text { Traversa, Enrico; International Center for Materials } \\
\text { Nanoarchitectonics (MANA), National Institute for Materials Science } \\
\text { (NIMS); University of Rome Tor Vergata, Department of Chemical } \\
\text { Science and Technology } \\
\text { Licoccia, Silvia; University of Rome Tor Vergata, Department of } \\
\text { Chemical Science and Technology }\end{array}$ \\
\hline Keywords: & $\begin{array}{l}\text { Direct Methanol Fuel Cell, Proton Exchange Membrane, Nafion, } \\
\text { Methanol Crossover, Performance Improvement }\end{array}$ \\
\hline
\end{tabular}

\section{scholarONE" \\ Manuscript Central}




\title{
Development of Nafion/Tin Oxide Composite MEA for DMFC applications
}

\author{
F.Chen ${ }^{1}$, B.Mecheri ${ }^{1}$, A.D’Epifanio ${ }^{1}$, E.Traversa ${ }^{1,2}$, and S.Licoccia ${ }^{1 *}$ \\ ${ }^{1}$ Department of Chemical Science and Technology, University of Rome "Tor Vergata", Via della Ricerca \\ Scientifica, 00133 Rome, Italy \\ ${ }^{2}$ International Center for Materials Nanoarchitectonics (MANA), National Institute for Materials Science \\ (NIMS), 1-1 Namiki, Tsukuba, Ibaraki 305-0044, Japan
}

Received

[*] Corresponding author, licoccia@ uniroma2.it

\begin{abstract}
Nafion composite membranes containing either hydrated tin oxide $\left(\mathrm{SnO}_{2} \cdot \mathrm{nH}_{2} \mathrm{O}\right)$ or sulfated tin oxide (S$\mathrm{SnO}_{2}$ ) at $5 \mathrm{wt} . \%$ and $10 \mathrm{wt} . \%$ were prepared and characterized. The structural and electrochemical features of the samples were investigated using X-ray diffraction, electrochemical impedance spectroscopy, methanol crossover, and direct methanol fuel cell (DMFC) tests. Highest conductivity values were obtained by using $\mathrm{S}-\mathrm{SnO}_{2}$ as filler $\left(0.094 \mathrm{Scm}^{-1}\right.$ at $\mathrm{T}=110^{\circ} \mathrm{C}$ and $\left.\mathrm{RH}=100 \%\right)$. The presence of the inorganic compound resulted in lower methanol crossover and improved DMFC performance with respect to a reference unfilled membrane. To improve the interface of the membrane electrode assembly (MEA), a layer of the composite electrolyte (i.e., the Nafion membrane containing $5 \mathrm{wt} \% \mathrm{~S}-\mathrm{SnO}_{2}$ ) was brushed on the electrodes, obtaining a DMFC operating at $110^{\circ} \mathrm{C}$ with a power density (PD) of 100 $\mathrm{mWcm}^{-2}$ which corresponds to a PD improvement of $52 \%$ with respect to the unfilled Nafion membrane.
\end{abstract}

Keywords: Direct Methanol Fuel Cells, Proton Exchange Membrane, Nafion, Methanol Crossover, Performance Improvement.

\section{Introduction}

Extensive research in the fields of materials chemistry and engineering has been carried out over the last decades with the aim of improving the efficiency of Direct Methanol Fuel Cells (DMFC) [1-4].

In particular, much work has been directed towards understanding the structure and proton transport properties of Nafion, the most widely used electrolyte for DMFC applications [5-7]. Despite its high proton conductivity and excellent chemical stability, Nafion performance, especially at high temperatures, is impaired by methanol crossover through the polymer membrane and by conductivity decay above 90 ${ }^{\circ} \mathrm{C}$ [8]. These drawbacks have been associated with the anisotropic swelling that Nafion undergoes at high temperature which damages the membrane dimensional stability [9] and also gives rise to interfacial complications, including high resistance and poor adhesion between membrane and electrodes [10].

Improved performance, both in terms of higher operating temperature and lower methanol crossover, have been reported for a variety of composite membranes [11-13]. In the case of composites containing hygroscopic oxides, such as $\mathrm{SiO}_{2}, \mathrm{TiO}_{2}$, or $\mathrm{ZrO}_{2}$, as fillers, the results have been attributed to the effect of filler surface characteristics on the water retention properties of the composite and/or to morphological variations of the composite membrane with respect to unfilled Nafion [14-16]. The amount of filler must be carefully controlled since an excessive loading of a non conducting inorganic species may be detrimental for the overall proton conductivity of the composite Nafion membrane [17].

To minimize proton conductivity losses induced by the incorporation of inorganics, the use of proton conducting fillers has been explored.

In particular, zirconium phosphate/Nafion composites have been found to exhibit a stable conductivity behavior up to $140^{\circ} \mathrm{C}$ at $\mathrm{RH}=90 \%[18,19]$. The enlarged stability domain of proton conductivity has been related to the higher stiffness of the composite membranes and thus to their enhanced dimensional stability [20]. The use of acidic fillers, such as heteropolyacids or sulfated metal oxides, has been also explored [21-25]. The acidic surface functionalities of inorganic fillers have been found to play a key role towards the improvement of the water retention properties of the composite membrane and thus of their transport properties. By an appropriate tailoring of the surface characteristics 
of different fillers ( such as $\mathrm{SiO}_{2}, \mathrm{PWA}-\mathrm{SiO}_{2}, \mathrm{ZrO}_{2}, \mathrm{Al}_{2} \mathrm{O}_{3}$ ), the power density of Nafion-based DMFCs have been improved up to $0.4 \mathrm{Wcm}^{-2}$ [26].

To obtain electrolytes characterized by good proton transport features, reduced methanol crossover and enhanced dimensional stability at $\mathrm{T}>90^{\circ} \mathrm{C}$, in this work we selected hydrated tin oxide $\left(\mathrm{SnO}_{2} \cdot \mathrm{nH}_{2} \mathrm{O}\right)$ and its sulfated derivative $\left(\mathrm{S}-\mathrm{SnO}_{2}\right)$ as fillers for the Nafion matrix.

$\mathrm{SnO}_{2} \cdot \mathrm{nH}_{2} \mathrm{O}$ is an inorganic proton conductor; when used as filler in a sulfonated polyether ether ketone (SPEEK) matrix gives rise to composites characterized by higher proton conductivity and lower methanol crossover than those of an unfilled SPEEK due to its capability to selectively reduce the tortuosity of the SPEEK membrane for proton transport and to avoid methanol permeation through the membrane $[27,28]$. Among all known solids, sulfated tin oxide $\left(\mathrm{S}-\mathrm{SnO}_{2}\right)$ is currently recognized as one of the strongest superacids $[29,30]$. While largely used as catalyst $[31,32]$, to our knowledge $\mathrm{S}-\mathrm{SnO}_{2}$ has never been explored as filler in composite polymer electrolyte membranes. With the aim of providing additional acidic sites to enhance proton transport, we exploited $\mathrm{S}-\mathrm{SnO}_{2}$ as filler of the Nafion membrane.

We here report a comparison of the properties of Nafion-based composites obtained by using either $\mathrm{SnO}_{2} \cdot \mathrm{nH}_{2} \mathrm{O}$ or $\mathrm{S}-\mathrm{SnO}_{2}$ and analyze the influence of the oxide surface acidic functionalization.

\section{Experimental \\ 2.1 Materials}

\subsubsection{Preparation of $\mathrm{SnO}_{2} \cdot \mathrm{nH}_{2} \mathrm{O}$ and $\mathrm{S}_{-} \mathrm{SnO}_{2}$}

Hydrated tin oxide $\left(\mathrm{SnO}_{2} \cdot n \mathrm{H}_{2} \mathrm{O}\right)$ was prepared according to the procedure previously reported [27, 28]. Sulfated tin oxide $\left(\mathrm{S}-\mathrm{SnO}_{2}\right)$ was obtained as follows [29]: $\mathrm{SnO}_{2} \cdot n \mathrm{H}_{2} \mathrm{O}$ was suspended in $3 \mathrm{M}$ sulfuric acid and stirred for $1 \mathrm{~h}$ at room temperature, then filtered and dried at room temperature for $1 \mathrm{~h}$. Finally, the powder was calcined at $500{ }^{\circ} \mathrm{C}$ in air for $3 \mathrm{~h}$ and then milled in an agate mortar.

\subsubsection{Preparation of composite membranes}

Composite membranes at $5 \mathrm{wt} . \%$ and $10 \mathrm{wt} . \%$ filler content were prepared as follows. Nafion perfluorinated resin solution at $5 \mathrm{wt} . \%$ in a mixture of lower aliphatic alcohols and water (Sigma-Adrich, CAS number 31175-20-9) (12 mL) was added to dimethylacetamide (DMA). The solution was heated to $80{ }^{\circ} \mathrm{C}$ to evaporate low-boiling solvents. During the evaporation step DMA was added to maintain the solution volume around $15 \mathrm{~mL}$. This process was repeated three times to ensure that the original solvent was replaced by DMA. 5 and $10 \mathrm{wt} \%$ (with respect to Nafion content) of either $\mathrm{SnO}_{2} \cdot n \mathrm{H}_{2} \mathrm{O}$ or S-SnO was dispersed in DMA and the resulting suspension was treated in an ultrasonic bath for 4 hours and then added to the Nafion solution. The suspension was then casted in a petri dish and dried at $80{ }^{\circ} \mathrm{C}$ overnight. Unfilled Nafion membranes were also prepared and used as reference. The thickness of the membranes ranged between 90-120 $\mu \mathrm{m}$. Before characterization, all the membranes were treated in a standard activation procedure using $\mathrm{H}_{2} \mathrm{O}_{2} 3 \mathrm{vol} \%$ solution, $0.5 \mathrm{M} \mathrm{H}_{2} \mathrm{SO}_{4}$ solution and distilled water, boiling the samples for 1 hour in each solution.

\subsection{Methods}

\subsubsection{XRD, EDX, FT-IR, and TG analyses}

The X-ray diffraction (XRD) analysis was carried out at room temperature by a PW 1729 X-ray generator (Philips International, Inc.) equipped with a $\mathrm{CuK} \alpha$ radiation source and graphite monochromator. XRD patterns were collected in the $2 \theta$ range of $5^{\circ}-60^{\circ}$ (step size: $2 \theta=0.02^{\circ}$; time per step: $2 \mathrm{~s})$.

The energy dispersive X-ray (EDX) microanalysis was performed at $10 \mathrm{keV}$ using an INCA Energy 300 spectrometer.

Fourier-transformed infrared spectra (FT-IR) were acquired by means of a Nexus 670 Thermo Nicolet FT-IR spectrometer (128 scans at a resolution of $\left.4 \mathrm{~cm}^{-1}\right)$. The powders were pelleted with $\mathrm{KBr}$ and analyzed in transmission mode. The ion exchange capacity (IEC) of the oxide powders was measured by potentiometric titrations [33]. A typical amount of $20 \mathrm{mg}$ of sample was dried at $60{ }^{\circ} \mathrm{C}$ under vacuum for 2 hours and then immersed in a $0.1 \mathrm{M} \mathrm{NaCl}$ overnight to exchange protons to $\mathrm{Na}^{+}$ions. The resulting solution were titrated with a $0.1 \mathrm{M} \mathrm{NaOH}$ solution to neutralize exchanged proton.

Thermogravimetric analysis (TG) was carried out in the $25-1000{ }^{\circ} \mathrm{C}$ temperature range, using a thermobalance (STA 409, Netzsch), in air flow $\left(80 \mathrm{mLmin}^{-1}\right.$ ) with a heating rate of $2{ }^{\circ} \mathrm{C} \mathrm{min} \mathrm{m}^{-1} \mathrm{~s}$ ).

\subsubsection{Conductivity}

Through-plane conductivity measurements were carried out on membrane disks of $6 \mathrm{~mm}$ in diameter, sandwiched between gas diffusion electrodes (E-Tek ELAT HT 140E-W with a Pt loading of $5 \mathrm{mg} \mathrm{cm}^{-2}$ ). 
By means of a Multichannel Potentiostat VMP3 (Princeton Applied Research), impedance spectra were acquired, applying a voltage of $20 \mathrm{mV}$ in a frequency range of $10 \mathrm{~Hz}-1 \mathrm{MHz}$. The membrane conductivity was calculated according to the equation 1 :

$\sigma=\mathrm{d} / \mathrm{RA}$

where $\mathrm{R}$ is the membrane resistance, $\mathrm{d}$ the distance between electrodes and $\mathrm{A}$ is the electrode area.

Conductivity of membranes was measured at $100^{\circ} \mathrm{C}$ and $110^{\circ} \mathrm{C}$ at $100 \%$ relative humidity.

\subsubsection{DMFC performance, in situ EIS, and methanol permeation measurements.}

Commercial Hydro2Power electrodes were used as anode and cathode, respectively: A-6

ELAT/SS/PtRu60-3-30PTFE/0.8N, custom $3 \mathrm{mgcm}^{-2}$ loading using 60\% HP Pt:Ru alloy (1:1) on Vulcan, $30 \mathrm{wt} \%$ PTFE with $0.8 \mathrm{mgcm}^{-2}$ Nafion, and A-6 ELAT/SS/Pt40-2-30PTFE/0.8 $\mathrm{N}$ custom $2 \mathrm{mgcm}^{-2}$ loading using $40 \% \mathrm{HP}$ Pt on Vulcan, $30 \mathrm{wt} \%$ PTFE with $0.8 \mathrm{mgcm}^{-2}$ Nafion. The membrane electrode assembly (MEA) was prepared, as extensively described in a previous work [34] sandwiching electrolyte membranes between anode and cathode by hot pressing at $120^{\circ} \mathrm{C}$ under $3.75 \mathrm{MPa}$ for 7 minutes.

A brushing technique was used to prepare functionalized electrodes. The commercial anode and cathode were treated in a vacuum oven at $80^{\circ} \mathrm{C}$ for 2 hours and then they were brushed with a $5 \mathrm{wt} . \% \mathrm{~S}$ $\mathrm{SnO}_{2} / \mathrm{Nafion}$ suspension in DMA. The brushed electrodes were placed in the vacuum oven at $80{ }^{\circ} \mathrm{C}$ for 2 hours to eliminate DMA residues and they were assembled with $\mathrm{N} \_5 \mathrm{~S}-\mathrm{SnO}_{2}$ membrane to prepare MEA.

DMFC performance was evaluated by placing the MEA in a single cell (ElectroChem) with active area of $5 \mathrm{~cm}^{2}$. A homemade test station was used, feeding the anode with a $2 \mathrm{M}$ methanol solution and the cathode with humidified oxygen. The feeding supply of methanol was monitored by a KNF's Model FEM 1.08 Liquid Metering Pump with control board (flow rate: $2.5 \mathrm{mLmin}^{-1}$, pressure: 2 abs bar). The oxygen supply was controlled by a MKS PR4000 mass-flow controller (flow rate: $100 \mathrm{sccm}$, pressure: 2 abs bar), and the humidifier temperature was opportunely set to ensure 100\% RH of the gas [34]. Polarization and power density curves were obtained using a Multichannel Potentiostat VMP3 (Princeton Applied Research) in the temperature range between 70 and $110^{\circ} \mathrm{C}$.

In situ EIS measurements were performed during the cell functioning, in potentiostatic mode $(0.3 \mathrm{~V})$. An AC sinusoidal perturbation (amplitude $15 \mathrm{mV}$ ) was introduced to the DC load, and impedance spectra were acquired by sweeping frequencies over the $500 \mathrm{kHz}-1 \mathrm{~Hz}$ range recording 10 points per decade.

For methanol permeation measurements, linear sweep voltammetry (LSV) was used to measure the steady-state limiting current density at cathode due to the oxidation of methanol permeating from the anode side. During the course of the experiment, the anode was fed by $2 \mathrm{M}$ methanol solution at a flow rate of $2 \mathrm{mLmin}^{-1}$. Humidified $\mathrm{N}_{2}$ was fed into the cathode. The limiting current density $\left(\mathrm{J}_{\text {lim }}\right)$ was measured at $80^{\circ} \mathrm{C}$, applying a voltage from 0 to $0.85 \mathrm{~V}$ (scan rate: $2 \mathrm{mVs}^{-1}$ ).

\section{Results and Discussion}

Figure 1 shows the XRD patterns of hydrated tin oxide $\left(\mathrm{SnO}_{2} \cdot \mathrm{nH}_{2} \mathrm{O}\right)$, and sulfated tin oxide $\left(\mathrm{S}-\mathrm{SnO}_{2}\right)$ powders. The XRD pattern of $\mathrm{SnO}_{2} \cdot \mathrm{nH}_{2} \mathrm{O}$ is characterized by broad peaks which reveal an amorphouslike state of the oxide. Some sharpening of the peaks, without any detectable shift, was observed in the XRD pattern of $\mathrm{S}_{-} \mathrm{SnO}_{2}$ as a result of increased crystallinity induced by heating to $500{ }^{\circ} \mathrm{C}$.

The energy dispersive $\mathrm{x}$-ray (EDX) microanalysis was used to assess and quantify the sulfur presence on the surface of the tin oxide particles. Figure 2 compares the EDX spectra of $\mathrm{SnO}_{2} \cdot n \mathrm{H}_{2} \mathrm{O}$ (Fig. 2a) and S$\mathrm{SnO}_{2}$ (Fig. 2b). While the EDX spectrum of $\mathrm{SnO}_{2} \cdot n \mathrm{H}_{2} \mathrm{O}$ displayed only the peaks due to tin and oxygen, the spectrum of $\mathrm{S}_{-} \mathrm{SnO}_{2}$ showed a further peak due to the sulfur presence. The Sn:O:S atomic ratio in the sulfated sample resulted to be 66.1:32.1:1.8.

In order to elucidate the structural features of the sulfur functionalities, FT-IR spectra were acquired on both oxides. Figure 3 shows the FT-IR spectra of $\mathrm{SnO}_{2} \cdot \mathrm{nH}_{2} \mathrm{O}$ and $\mathrm{S}-\mathrm{SnO}_{2}$. The $\mathrm{SnO}_{2} \cdot \mathrm{nH}_{2} \mathrm{O}$ sample displayed a broad absorption band in the region $3600-2500 \mathrm{~cm}^{-1}$ which can be ascribed to H-bonded hydroxyl groups coupled with physisorbed water molecules. The band centered at $1600 \mathrm{~cm}^{-1}$ corresponds to -OH bending mode of water molecules[35, 36]. The FT-IR spectra of the sulfated samples shows some differences both in the frequency region of $\mathrm{O}-\mathrm{H}$ stretching and, especially, in the frequency range of the $\mathrm{SO}_{4}{ }_{4}^{2-}$ stretching vibration. In particular, the shoulder at $2870 \mathrm{~cm}^{-1}$ associated to the main peak became more evident, this being ascribed to hydroxyls perturbations induced by neighboring sulfate groups. Moreover, new absorption bands at $975,1050,1152,1213 \mathrm{~cm}^{-1}$ are clearly visible. According to previous literature reports [37-39], the main peak centered at $1150 \mathrm{~cm}^{-1}$ can be ascribed to the symmetric stretching of $\mathrm{S}=\mathrm{O}$ vibrations, the splitting of this peak being characteristic of the formation of bidentate sulfate groups coordinated to the tin particles. 
To evaluate the effect of the functionalization on the surface acidity of the tin oxide, IEC values of both oxide powders were measured and they were found to be $0.352 \mathrm{meq} \mathrm{g}{ }^{-1}$ and 1.42 meq g $\mathrm{g}^{-1}$, for $\mathrm{SnO}_{2} \cdot \mathrm{nH}_{2} \mathrm{O}$ and $\mathrm{S}-\mathrm{SnO}_{2}$, respectively. These values are in good agreement with ion-exchange capacity of metal oxides including hydrated tin oxide [40-42]. The increased IEC of the sulfated sample revealed the enhanced acidity of $\mathrm{S}-\mathrm{SnO}_{2}$ with respect to $\mathrm{SnO}_{2} \cdot \mathrm{nH}_{2} \mathrm{O}$ provided by the surface functionalization of the filler.

To study the thermal evolution of the two fillers, thermogravimetric (TG) analysis was carried out on the oxide powders. Figure 4 shows the TG curves of $\mathrm{SnO}_{2} \cdot \mathrm{nH}_{2} \mathrm{O}$ and $\mathrm{S}-\mathrm{SnO}_{2}$ powders. As far as $\mathrm{SnO}_{2} \cdot \mathrm{nH}_{2} \mathrm{O}$ is concerned, the main weight loss (about $12 \%$ of the total loss), observed in the $50-150{ }^{\circ} \mathrm{C}$ range, can be attributed to the loss of physisorbed water, while the loss of structural and bound water occurred gradually between 250 and $450{ }^{\circ} \mathrm{C}$ [43-45]. The TG profile of $\mathrm{S}-\mathrm{SnO}_{2}$ shows two different weight losses; the first one, occurring in the $50-150{ }^{\circ} \mathrm{C}$ range, corresponds to water desorption, whereas the weight loss occurring in the $600-760{ }^{\circ} \mathrm{C}$ range (about $4 \%$ of the total loss) can be attributed to the splitting off of sulfate groups bound to the surface of $\mathrm{SnO}_{2}$ crystallites [46]. TG analysis thus revealed that the acidic surface functionalities are thermally stable in the temperature range of interest for DMFC applications.

Composite Nafion-based membranes containing $5 \mathrm{wt} . \%$ and $10 \mathrm{wt} . \%$ of either $\mathrm{SnO}_{2} \cdot \mathrm{nH}_{2} \mathrm{O}\left(\mathrm{N}_{-} 5 \mathrm{SnO}_{2}\right.$ and $\left.\mathrm{N}_{-} 10 \mathrm{SnO}_{2}\right)$ or $\mathrm{S}-\mathrm{SnO}_{2}\left(\mathrm{~N} \_5 \mathrm{~S}-\mathrm{SnO}_{2}\right.$ and $\left.\mathrm{N} \_10 \mathrm{~S}-\mathrm{SnO}_{2}\right)$ were prepared. To evaluate the suitability of such composites as proton conducting electrolytes, proton conductivity $(\sigma)$ of all membranes was measured and the corresponding values at $100^{\circ} \mathrm{C}$ and $110^{\circ} \mathrm{C}$ are shown in Figure 5. At both temperatures, $\sigma$ of the composites was higher than that of a reference Nafion recast membrane (N_RC) with the exception of $\mathrm{N}_{-} 10 \mathrm{SnO}_{2}$ where the decrease of proton charge carriers caused by the presence of a large amount of filler appears to dominate the electrochemical properties. The highest $\sigma$ values were shown by membrane N_5S- $\mathrm{SnO}_{2}$ as a result of the enhanced acidity of $\mathrm{S}-\mathrm{SnO}_{2}$ with respect to $\mathrm{SnO}_{2} \cdot \mathrm{nH}_{2} \mathrm{O}$ provided by the surface functionalization of the filler [47]. $\sigma$ values are indeed all comprised in a narrow range, each sample meeting proton conductivity requirements for DMFC applications [48].

It is noteworthy that proton conductivity of the unfilled Nafion membrane decreased as the temperature increased from $100{ }^{\circ} \mathrm{C}$ to $110^{\circ} \mathrm{C}$, whereas $\sigma$ of the $5 \mathrm{wt} . \%$ composites increased. It appears then that at such loading the presence of the filler allowed to extend to higher temperatures the stability range of proton conductivity. This finding is in good agreement with previous work on the effect of superacid zirconia on the proton conductivity of Nafion membranes [12,23,25].

To check the applicability of the composite Nafion based membranes in a real device, the electrochemical performance of the membranes was tested in a DMFC single cell, acquiring polarization curves. Figure 6 shows polarization (I-V) and power density (PD) curves for the unfilled Nafion and composite membranes at $\mathrm{T}=100{ }^{\circ} \mathrm{C}$ (Fig. 6a) and $\mathrm{T}=110^{\circ} \mathrm{C}$ (Fig. 6b). At $\mathrm{T}=100{ }^{\circ} \mathrm{C}$, the unfilled Nafion and the $\mathrm{N}_{-} 5 \mathrm{SnO}_{2}$ sample showed similar performance $\left(\mathrm{PD}_{\max }=68 \mathrm{mWcm}^{-2}, \mathrm{I}_{(0.15 \mathrm{~V})}=370 \mathrm{mAcm}^{-2}\right.$, for $\mathrm{N} \_5 \mathrm{SnO}_{2}$ sample), whereas the performance of $\mathrm{N} \_5 \mathrm{~S}-\mathrm{SnO}_{2}$ sample was found to be higher $\left(\mathrm{PD}_{\max }=76\right.$ $\mathrm{mWcm}^{-2}$ and $\left.\mathrm{I}_{(0.15 \mathrm{~V})}=415 \mathrm{mAcm}^{-2}\right)$.

Increasing the temperature from $100{ }^{\circ} \mathrm{C}$ to $110^{\circ} \mathrm{C}$ caused a decrease of the N_RC membrane performance, according to its well-known loss in stability above $90{ }^{\circ} \mathrm{C}$. On the contrary, the N_5 $\mathrm{SnO}_{2}$ sample maintained almost the same PD and I values with respect to those recorded at $100{ }^{\circ} \mathrm{C}$, whereas the performance of the N_5S-SnO $\mathrm{S}_{2}$ sample kept increasing $\left(\mathrm{PD}_{\max }=82 \mathrm{mWcm}^{-2}\right.$ and $\left.\mathrm{I}_{(0.15 \mathrm{~V})}=443 \mathrm{mAcm}^{-2}\right)$. Such enhancement cannot be ascribed exclusively to the difference in conductivity values which were not so dissimilar to justify the improved PD and I curves.

To better understand the reasons why composites showed a performance superior to that of the unfilled Nafion membrane, firstly we evaluated the effect of the filler on methanol crossover. Limiting methanol permeation current density $\left(\mathrm{J}_{\text {lim }}\right)$ values through the unfilled Nafion and composite membranes were thus measured. Figure 7 shows a typical voltammetric curve resulting from electro-oxidation of methanol permeating the $\mathrm{N} \_5 \mathrm{SnO}_{2}$ membrane, $\mathrm{J}_{\mathrm{lim}}$ value corresponding to the current densities plateau. The inset of Figure 7 shows $\mathrm{J}_{\mathrm{lim}}$ values for $\mathrm{N} \_\mathrm{RC}, \mathrm{N} \_5 \mathrm{SnO}_{2}$, and $\mathrm{N} \_5 \mathrm{~S}-\mathrm{SnO}_{2}$ membranes. Composites displayed lower $\mathbf{J}_{\lim }$ than unfilled Nafion. The extent of the reduction of $\mathbf{J}_{\lim }$ was $7 \%$, and $50 \%$, for N_5 $\mathrm{SnO}_{2}, \mathrm{~N} \_5 \mathrm{~S}-\mathrm{SnO}_{2}$, respectively.

It is well-known that microstructure strongly influences the methanol transport properties of the electrolyte [8]. The possible occurrence of structural changes in the case of composites with respect to the unfilled Nafion membrane was investigated by XRD.

Figure 8 shows the XRD profiles of N_RC, N_5 $\mathrm{SnO}_{2}$, and N_5S-SnO 2 samples. In agreement with earlier reports [49-51], the recast Nafion membrane displayed a broad diffraction feature at $2 \theta=12-22^{\circ}$ which can be separated through deconvolution into two peaks, assigned to amorphous $\left(2 \theta=16^{\circ}\right)$ and 
crystalline $\left(2 \theta=17.50^{\circ}\right)$ scattering from the polyfluorocarbon chains of Nafion. Crystallinity $\left(\mathrm{X}_{\mathrm{cr}}\right)$ can be calculated from the ratio between the areas of the deconvoluted peaks. While crystallinity of recast Nafion was found to be $25 \%$, in good agreement with the literature [50,51] the crystallinity of the composite membranes was higher, being $28 \%$ and $30 \%$ for $\mathrm{N} \_5 \mathrm{SnO}_{2}$, and $\mathrm{N} \_5 \mathrm{~S}-\mathrm{SnO}_{2}$ samples, respectively. This finding can be ascribed to a different crystalline structure or morphology induced by polymer/filler interactions. The increased crystallinity of composites obtained by incorporating different fillers in a Nafion membrane has already been reported [ 52, 53]. It is widely recognized that methanol crossover takes place both in the hydrophilic channel structure and in the hydrophobic backbone of the perfluorosulphonic ionomer [54, 55]. The increased crystallinity of the composites is indicative of a more compact hydrophobic region of the Nafion matrix which hinders the methanol infiltration thus explaining the reduced methanol crossover of composites with respect to the N_RC sample [56, 57].

The impedance characteristics of the DMFC under different operating temperatures $\left(70-100{ }^{\circ} \mathrm{C}\right)$ were also investigated. All MEA components, except the membrane, were identical, therefore, the difference in the impedance spectra can be ascribed to the membrane and to the membrane/electrode interface. MEAs based on $\mathrm{N} \_\mathrm{RC}, \mathrm{N} \_5 \mathrm{SnO}_{2}$, and $\mathrm{N} \_5 \mathrm{~S}-\mathrm{SnO}_{2}$ membranes were tested and the corresponding impedance spectra recorded at $90^{\circ} \mathrm{C}, 100{ }^{\circ} \mathrm{C}$ and $110^{\circ} \mathrm{C}$ are shown in Figure 9. All the spectra are characterized by the presence of two arcs, the high frequencies one accounting for the charge transfer and the low frequencies one accounting for mass transfer processes. The equivalent circuit, used to fit the spectra, is shown as an inset in Figure 9. $R_{\text {ele }}, R_{c t}$, and $R_{\text {mass }}$ represent the ohmic resistance, charge transfer resistance and mass transfer resistance, respectively. $\mathrm{R}_{\mathrm{ct}}$ accounts for both anode and cathode side, including methanol electro-oxidation and oxygen reduction reaction. On the other hand, since the cathode is fed with pure $\mathrm{O}_{2}, \mathrm{R}_{\text {mass }}$ is dominated by methanol transport occurring at the anode side. $\mathrm{L}$ represents the inductive contributions and $\mathrm{CPE}$ is a constant phase element which replaces the conventional doublelayer capacitance [58-61]. In the $70-110{ }^{\circ} \mathrm{C}$ range, $\mathrm{R}_{\text {ele }}$ was found to be weakly dependent on temperature for all samples; moreover, the differences in $\mathrm{R}_{\text {ele }}$ values of the three MEAs were not large enough to account for the different electrochemical performance showed in Figure 6. Therefore, such difference is mainly due to $R_{c t}$ and $R_{\text {mass }}$ which are related to the membrane/electrode interface.

Figure 10 shows the variation of $\mathrm{R}_{\mathrm{ct}}$ (Figure 10a), and $\mathrm{R}_{\text {mass }}$ (Figure 10b), for the three MEAs as a function of temperature. At temperatures below $90{ }^{\circ} \mathrm{C}$ both resistances decreased for all samples. Above such temperature $R_{c t}$ and $R_{\text {mass }}$ show an abrupt increase for sample N_RC, while the values relative to the composites showed a steady decrease. The difference between unfilled Nafion and composites membranes is most evident at $100{ }^{\circ} \mathrm{C}$ and $110^{\circ} \mathrm{C}$, and highest in the case of $\mathrm{N}_{-} 5 \mathrm{~S}-\mathrm{SnO}_{2}$, thus explaining the increased electrochemical performance shown in Figure 6 for such membrane.

The decrease of $R_{c t}$ and $R_{\text {mass }}$ observed for the composites is certainly related to the improved membrane/electrode interface stability associated with the superior dimensional stability induced by the presence of the fillers. To further enhance the quality of the electrolyte/electrodes interface the Nafion containing electrodes were brushed with a $\mathrm{S}-\mathrm{SnO}_{2} / \mathrm{Nafion}$ suspension to avoid the interfacial discontinuities and possible lack of adhesion expected when the unfilled Nafion membrane is replaced with the composite to assemble the MEA.

Figure 11 shows the resulting I-V and PD curves measured for the $\mathrm{N} \_5 \mathrm{~S}-\mathrm{SnO}_{2}$ sample at $100{ }^{\circ} \mathrm{C}$ and $110^{\circ} \mathrm{C}$. Comparing the data obtained with commercial electrodes at the two temperatures (Figure 6), it appears that the electrode modification lead to improved performance: in particular, a $32 \%$ and a $22 \%$ increase in PD were observed at $100{ }^{\circ} \mathrm{C}$ and $110^{\circ} \mathrm{C}$, respectively. The best performance was observed at $110^{\circ} \mathrm{C}$, being $\mathrm{PD}_{\max }=100 \mathrm{mWcm}^{-2}$ and $\mathrm{I}_{(0.15 \mathrm{~V})}=488 \mathrm{mAcm}^{-2}$.

In-situ EIS spectra of the $\mathrm{N} \_5 \mathrm{~S}-\mathrm{SnO}_{2}$ cell equipped with modified electrodes were also acquired. Figure 12 shows the impedance spectra recorded at $90^{\circ} \mathrm{C}, 100^{\circ} \mathrm{C}$ and $110^{\circ} \mathrm{C}$, the inset showing $\mathrm{R}_{\mathrm{ct}}$ and $R_{\text {mass }}$ as a function of temperature in the $70-110{ }^{\circ} \mathrm{C}$ range. Both $R_{c t}$ and $R_{\text {mass }}$ decrease as the temperature increased; $R_{\text {mass }}$ values were similar to that recorded for the unbrushed MEA, while $R_{c t}$ values were appreciably lower indicating that the brushing technique is a successful method to enhance the electrode/electrolyte interface.

Combining the brushing technique with the use of $\mathrm{N} \_5 \mathrm{~S}-\mathrm{SnO}_{2}$ composite membrane as electrolyte allowed to enable the Nafion membrane to endure higher temperatures, achieving at $110{ }^{\circ} \mathrm{C}$ a power density improvement of $52 \%$ with respect to the unfilled Nafion membrane.

\section{Conclusions}


The introduction of proton conducting fillers such as hydrated tin oxide $\left(\mathrm{SnO}_{2} \cdot \mathrm{nH}_{2} \mathrm{O}\right)$ and its sulfated derivative $\left(\mathrm{S}-\mathrm{SnO}_{2}\right)$ have a positive effect of on the properties of Nafion membranes. The higher degree of crystallinity of the composites with respect to a polymer unfilled membrane indicated by XRD measurements demonstrate that such structural modification results in reduced methanol crossover (up to $50 \%$ ) as derived from $\mathbf{J}_{\text {lim }}$ measurements. The additional acidic sites provided by the superacidic inorganic compound where bidentate sulfate groups are coordinated to the oxide particles $\left(\mathrm{S}-\mathrm{SnO} \mathrm{O}_{2}\right)$ also improved the proton transport characteristics of the Nafion membrane.

When assembled in a MEA, such composite electrolytes display an enhanced membrane/electrode interface stability as revealed by electrochemical impedance spectroscopy. The adhesion and chemical continuity of such interface can be further improved by incorporating the sulfated filler on the electrodes. MEAs fabricated with modified electrodes and composite Nafion membrane containing $5 \mathrm{wt} \% \mathrm{~S}-\mathrm{SnO}_{2}$ allowed to operate a DMFC at $110{ }^{\circ} \mathrm{C}$ obtaining $\mathrm{PD}_{\max }=100 \mathrm{mWcm}^{-2}$, and $\mathrm{I}_{(0.15 \mathrm{~V})}=488 \mathrm{mAcm}^{-2}$, i.e. a $52 \%$ power density improvement with respect to the unfilled Nafion membrane.

\section{Acknowledgments}

The financial support of the Ministry for Foreign Affairs (Italy-Quebec Joint Lab for Advanced Nanostructured Materials for Energy, Catalysis and Biomedical Applications) is gratefully acknowledged.

Thanks are due to Prof. Ana Tavares (INRS-EMT, Varennes, Québec, CANADA) for help in collecting and discussing FT-IR spectra.

\section{References}

[1] S. Wasmus, A. Küver, J. Electroanal. Chem. 1999, 461, 14.

[2] X. Ren, P. Zelenay, S. Thomas, J. Davey and S. Gottesfeld, J. Power Sources 2000, 86, 111.

[3] N.W. De Luca, Y.A. Elabd, J. Polymer Sci. Part B: Polymer Physics 2006, 44, 2201.

[4] V. Neburchilov, J. Martin, H. Wang, J. Zhang, J. Power Sources 2007, 169, 221.

[5] S. J. Paddison and R. Paul, Phys. Chem. Chem. Phys. 2002, 4, 1158.

[6] K.A. Mauritz, R.B. Moore, Chem. Rev. 2004, 104, 4535.

[7] D. E. Moilanen, D. B. Spry, and M. D. Fayer, Langmuir 2008, 24, 3690.

[8] K.D. Kreuer, J. Membrane Sci. 2001, 185, 29

[9] M. Casciola, G. Alberti, M. Sganappa, R. Narducci, J. Power Sources 2006, 162, 141.

[10] C.H. Lee, S.Y. Lee, Y.M. Lee, S.Y. Lee, J.W. Rhim, O. Lane, and J.E. McGrath, ACS Appl. Mater. Interfaces 2009, 1, 1113.

[11] G. Alberti M. Casciola, Annu. Rev. Mater. Res. 2003, 33,129;

[12] D. Jones, J. Roziere, Adv. Polym. Sci. 2008, 215, 219

[13] P.L. Antonucci, A.S. Aricò, P. Cretì, E. Ramunni, V. Antonucci, Solid State Ionics 1991, 25, 431

[14]N. Miyake, J.S. Wainright and R.F. Savinell, J. Electrochem. Soc. 2001, 148, A905

[15] V. Baglio, A.S. Aricò, A. Di Blasi, V. Antonucci, P.L. Antonucci, S. Licoccia, E. Traversa, F. Serraino Fiory, Electrochimica Acta 2005, 50, 1241.

[16] N.H. Jalani, K.Dunn, R.Datta, Electrochimica Acta 2005, 51, 553.

[17] D.H. Jung, S.Y. Cho, D.H. Peck, D.R. Shin and J.S. Kim, J. Power Sources 2002, 106, 173.

[18] G. Alberti, M. Casciola, D. Capitani, A. Donnadio, R. Narducci, M. Pica, M. Sganappa, Electrochimica Acta 2007, 52, 8125.

[19] P. Costamagna, C. Yang, A.B. Bocarsly, S. Srinivasan, Electrochim. Acta 2002, 47,1023.

[20] M.Casciola, D.Capitani, A.Comite, A.Donaddio, V.Frittella, M.Pica, M.Sganappa, and A.Varzi, Fuel Cells 2008, 3-4, 217.

[21] S. Malhotra, R. Datta, J. Electrochem. Soc. 1997, 144, L23.

[22] T.M. Thampan, N.H. Jalani, P. Choi, R. Datta, J. Electrochem. Soc. 2005, 152, A316.

[23] M.A.Navarra, F.Croce, and B.Scrosati, J. Mater. Chemistry 2007, 17, 3210.

[24] M.A. Navarra, C.Abbate, B.Scrosati, J. Power Sources 2008, 183, 109.

[25] A. D’Epifanio, M. A. Navarra, F. C. Weise, B. Mecheri, J. Farrington, S. Licoccia and S. Greenbaum, Chem. Mater., DOI:10.1021/cm901486t.

[26] A.S.Aricò, V.Baglio, A. Di Blasi, P.Creti, P.L. Antonucci, V.Antonucci, Solid State Ionics 2003,161, 251.

[27] B.Mecheri, A.D'Epifanio, E.Traversa and S.Licoccia, J. Power Sources 2008, 178, 554.

[28] B.Mecheri, A. D’Epifanio, L. Pisani, F. Chen, E. Traversa, F. C.Weise, S. Greenbaum, and S. Licoccia, Fuel Cells 2009, 4, 372. 
[29 ] H. Matsuhashi, H. Miyazaki, Y. Kawamura, H. Nakamura, and K. Arata, Chem. Mater. 2001, 13, 3038.

[30] A.S. Khder, A.I. Ahmed, Applied Catalysis A: General 2009, 354, 153-160.

[31] S Furuta, H Matsuhashi, K Arata, Catal. Commun. 2004, 5, 721.

[32] S Furuta, H Matsuhashi, K Arata, Applied Catalysis A: General, 2004, 257, 213.

[33] N.Spanos, I.Georgiadou, and A.Lycourghiotis, J.Coll.Int.Sci. 1995, 172, 374.

[34]A. D’Epifanio, B. Mecheri, E. Fabbri, A.Rainer, E. Traversa and S. Licoccia J. Electrochem. Soc., 2007, 154, B1148.

[35] A. Gamard, O. Babot, B. Jousseaume, M.-C. Rascle, T. Toupance, and G. Campet, Chem. Mater. 2000, 12, 3419-3426.

[36] J.Zhang and L.Gao, J. Solid State Chem. 2004, 177, 1425.

[37] H. Matsuhashi, M. Hino, K. Arata, Appl. Catal. 1990, A59, 205.

[38] S. Furuta, H. Matsuhashi,K. Arata Applied Catalysis A: 2004, 269, 187-191.

[39] M.A. Martin, J.W. Childers, and R.A. Palmer, Appl. Spectrosc., 1987, 41,120.

[40] H. Tamura, A. Tanaka, K. Mita, and R. Furuichi, Journal of Colloid and Interface Science 1999, 209, 225-231.

[41] W.A. England, M.G. Cross, A.Hammett, P.J. Wiseman and J.B. Goodenough, Solid State Ionics, 1980, 1,231

[42] A.S. Khder, E.A. El-Sharkawy, S.A. El-Hakam , A.I. Ahmed, Catalysis Communications 2008, 9, 769-777.

[43] S. Hara, H. Sakamoto, M. Miyayama and T. Kudo, Solid State Ionics 2002, 154-155, 679.

[44] S. Hara, S. Takano and M. Miyayama, J. Phys. Chem. B 2004, 108, 634.

[45] E.W. Giesekke, H.S. Gutowsky, P. Kirkov and H.A. Laitenen, Inorg. Chem. 1967, 6, 1294

[46] R. Gutiérrez-Báez, J. A. Toledo-Antonio, M. A. Cortes-Jácome, P. J. Sebastian, and A. Vázquez, Langmuir 2004, 20, 4265.

[47] H.Matsuhashi, M. Hino, K.Arata, Chem. Lett. 1988, 1027.

[48] Vladimir Neburchilov, Jonathan Martin, Haijiang Wang, Jiujun Zhang, Journal of Power Sources 2007,169, 221-238.

[49] R.B. Moore III, C.R. Martin, Macromolecules 1988, 21, 1334.

[50] T.D. Gierke, G.E. Munn, F.C. Wilson, J. Polym. Sci. Phys. 1981, 19, 1687.

[51] M. Fujimura, T. Hashimoto, and H. Kawai, Macromolecules 1981, 14, 1309.

[52] F. Bauer, M. Willert-Porada, J. Membrane Sci. 2004, 233, 141.

[53] Z. Wu, G. Sun, W. Jin, H. Hou, S. Wang, Q. Xin, J. Membrane Sci. 2008, 313, 336.

[54] P. Dimitrova, K.A. Friedrich, U. Stimming, B. Vogt, Solid State Ionics 2002, 150, 115.

[55] A. Heinzel, V.M. Barragan, J. Power Sources 1999, 84, 70.

[56] P. Dimitrova, K.A. Friedrich , B. Vogt, U. Stimming J. Electroanal. Chem. 2002, 532, 75.

[57] Y.S. Park, Y. Yamazaki, Solid State Ionics 2005, 176, 1079.

[58] Mueller, J. T.; Urban, P. M. J. Power Sources 1998, 75, 139.

[59] P. Piela, R. Fields and P. Zelenay, J. Electrochem. Soc. 2006,153, A1902.

[60] X.Yuan, H.Wang, J.C. Sun, J. Zhang, Int. J. Hydrogen Energy 2007, 32, 4365.

[61] S.Seo and C.S. Lee, Energy \& Fuels 2008, 22, 1204. 


\section{Figure Captions}

Fig. 1 XRD patterns of $\mathrm{SnO}_{2} \cdot n \mathrm{H}_{2} \mathrm{O}$ and $\mathrm{S}-\mathrm{SnO}_{2}$ powders.

Fig. 2 EDX spectrum of $\mathrm{SnO}_{2} \cdot \mathrm{nH}_{2} \mathrm{O}$ and $\mathrm{S}-\mathrm{SnO}_{2}$

Fig. 3 FT-IR spectra of $\mathrm{SnO}_{2} \cdot \mathrm{nH}_{2} \mathrm{O}$ and $\mathrm{S}-\mathrm{SnO}_{2}$

Fig. 4 TG profiles of $\mathrm{SnO}_{2} \cdot n \mathrm{H}_{2} \mathrm{O}$ and $\mathrm{S}-\mathrm{SnO}_{2}$ powders.

Fig. 5 Proton conductivity values of unfilled Nafion and composite membranes at $100^{\circ} \mathrm{C}$ and $110^{\circ} \mathrm{C}$ (RH=100\%).

Fig. 6 Polarization and power density curves of unfilled Nafion and composite membranes at (a) $\mathrm{T}=100^{\circ} \mathrm{C}$ and (b) $\mathrm{T}=110^{\circ} \mathrm{C}$. Anode feed: $2 \mathrm{M}$ aqueous methanol, flow rate $2.5 \mathrm{mLmin}^{-1}$, pressure $2 \mathrm{abs}$ bar. Cathode feed: $\mathrm{O}_{2}$ flow rate $100 \mathrm{sccm}$, pressure 2 abs bar

Fig. 7 Voltammetric curve for the oxidation of methanol permeating through the $\mathrm{N} \_5 \mathrm{SnO}_{2}$ membrane exposed to a $2 \mathrm{M}$ methanol feed. $\mathrm{T}=80^{\circ} \mathrm{C}$. Inset: Limiting current density $\left(\mathrm{J}_{\mathrm{lim}}\right)$ values of $\mathrm{N} \_\mathrm{RC}, \mathrm{N} \_5 \mathrm{SnO}_{2}$, and $\mathrm{N} \_5 \mathrm{~S}-\mathrm{SnO}_{2}$ membranes.

Fig. 8 XRD patterns of N_RC, $\mathrm{N} \_5 \mathrm{SnO}_{2}$, and $\mathrm{N} \_5 \mathrm{~S}-\mathrm{SnO}_{2}$ membranes.

Fig. 9 Impedance spectra of MEAs made up with N_RC, N_5 $5 \mathrm{SnO}_{2}$ and $\mathrm{N} \_5 \mathrm{~S}-\mathrm{SnO}_{2}$ membranes as electrolytes, during DMFC functioning at $90^{\circ} \mathrm{C}, 100^{\circ} \mathrm{C}$ and $110^{\circ} \mathrm{C}$. Anode feed: $2 \mathrm{M}$ aqueous methanol. Cathode feed: $\mathrm{O}_{2}$.

Fig. 10 Charge transfer resistance, $R_{c t}(a)$ and mass transfer resistance, $R_{\text {mass }}(b)$ as a function of temperature for MEAs made up with $\mathrm{N} \_\mathrm{RC}, \mathrm{N} \_5 \mathrm{SnO}_{2}$ and $\mathrm{N} \_5 \mathrm{~S}-\mathrm{SnO}_{2}$ membranes as electrolytes.

Fig. 11 Polarization and power density curves of the MEA prepared by brushing and containing N_5S$\mathrm{SnO}_{2}$ membrane as electrolyte at (a) $\mathrm{T}=100^{\circ} \mathrm{C}$ and (b) $\mathrm{T}=110^{\circ} \mathrm{C}$. Anode feed: $2 \mathrm{M}$ aqueous methanol, flow rate $2.5 \mathrm{mLmin}^{-1}$, pressure 2 abs bar. Cathode feed: $\mathrm{O}_{2}$ flow rate $100 \mathrm{sccm}$, pressure 2 abs bar. Fig.12 Impedance spectra of the MEA prepared by brushing and containing $\mathrm{N}_{-} 5 \mathrm{~S}-\mathrm{SnO}_{2}$ membrane as electrolyte, during DMFC functioning at $90^{\circ} \mathrm{C}, 100^{\circ} \mathrm{C}$ and $110^{\circ} \mathrm{C}$. Anode feed: $2 \mathrm{M}$ aqueous methanol. Cathode feed: $\mathrm{O}_{2}$. Inset: Charge transfer resistance, $\mathrm{R}_{\mathrm{ct}}$ (a) and mass transfer resistance, $\mathrm{R}_{\text {mass }}$ (b) as a function of temperature. 


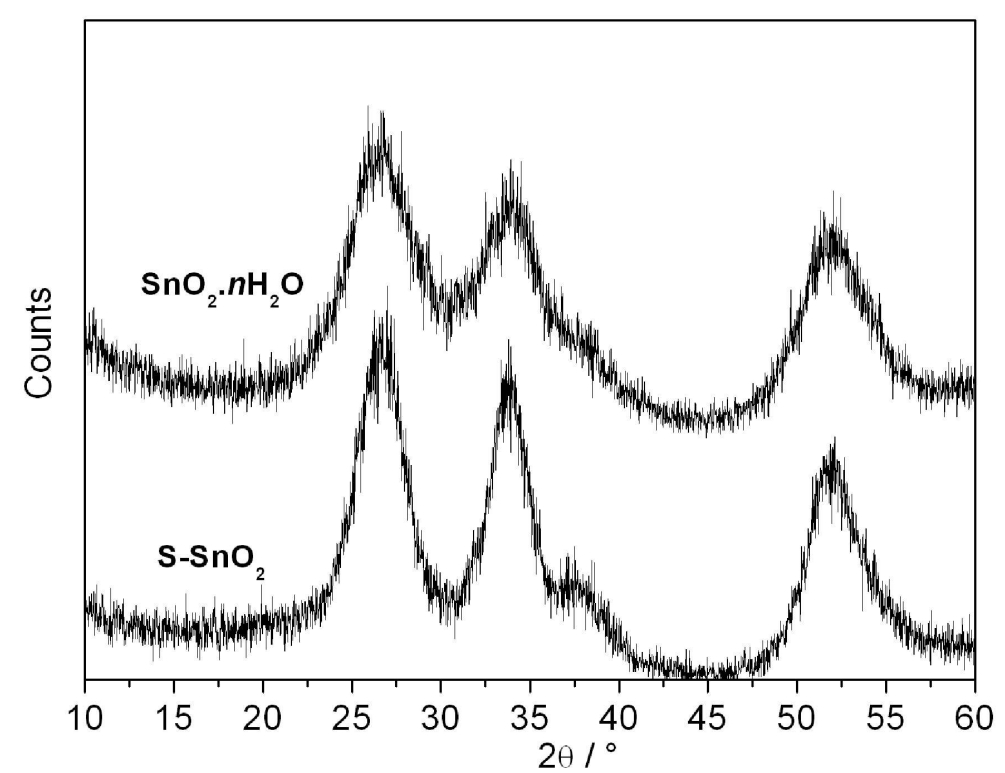

Fig. 1 XRD patterns of $\mathrm{SnO}_{2} \bullet \mathrm{nH} 2 \mathrm{O}$ and S-SnO2 powders. $297 \times 209 m m$ (200 x 200 DPI) 


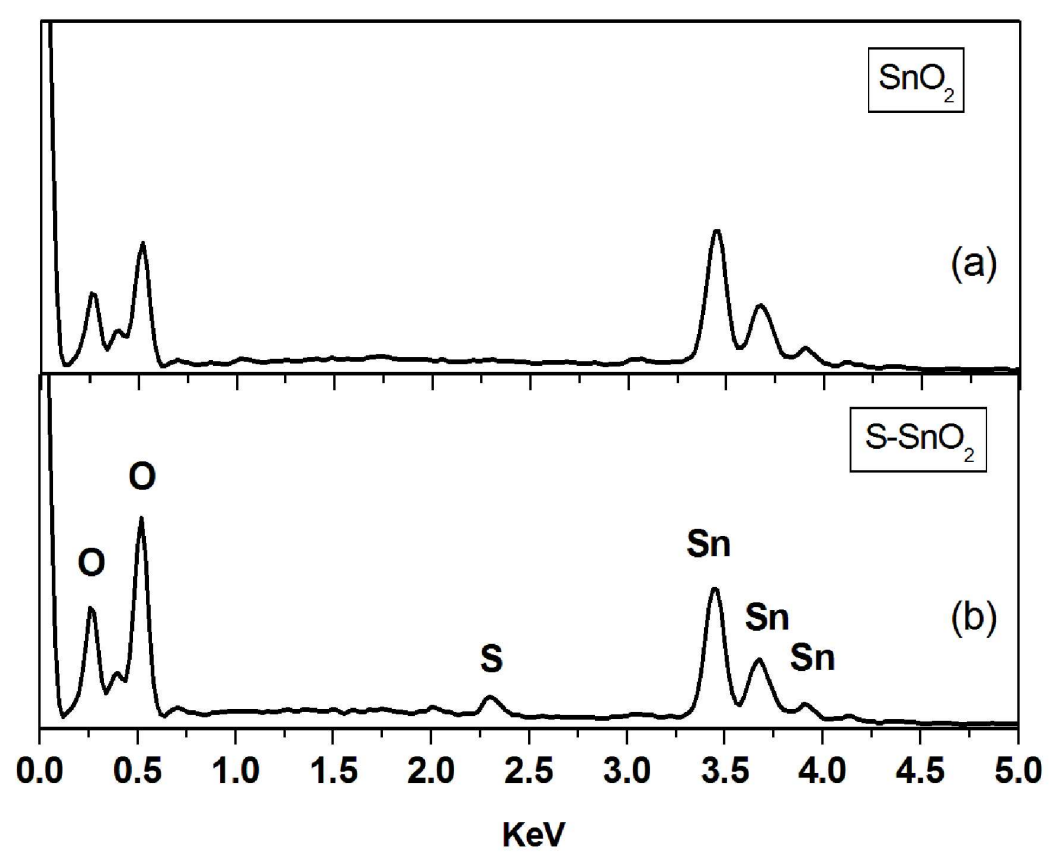

$279 \times 215 \mathrm{~mm}(200 \times 200$ DPI $)$ 


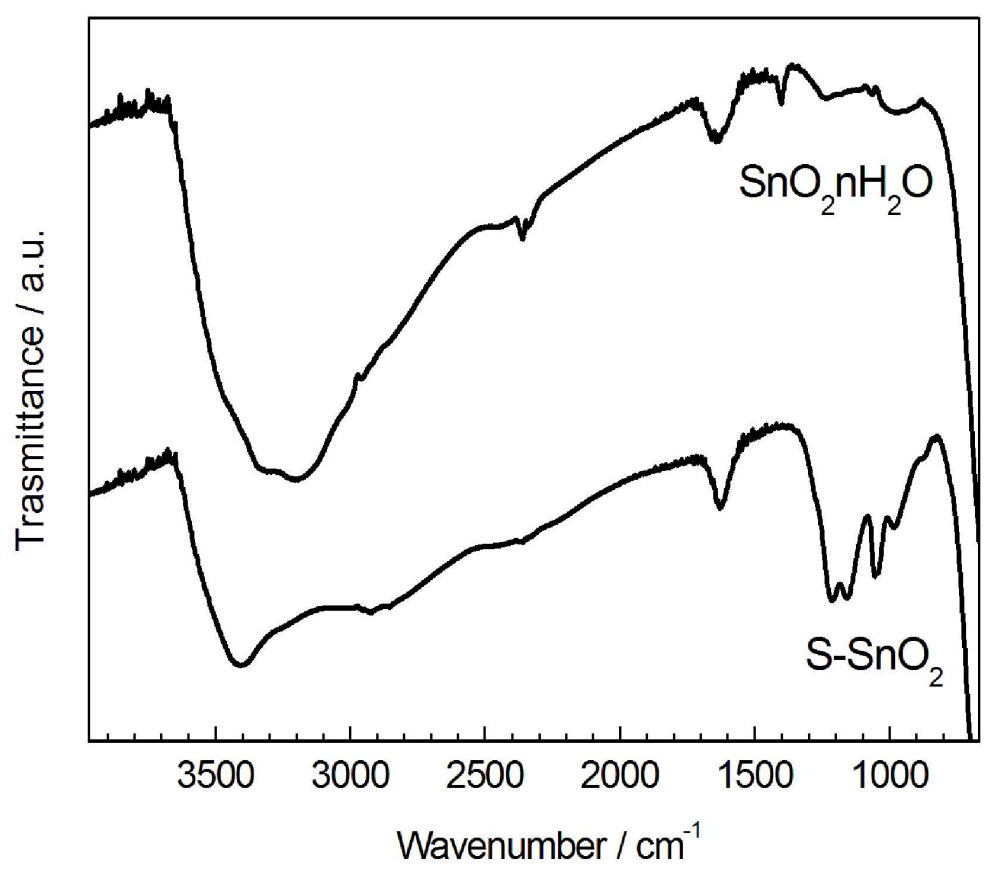

Fig. 3 FT-IR spectra of $\mathrm{SnO} 2 \bullet \mathrm{nH} 2 \mathrm{O}$ and S-SnO2 $279 \times 215 \mathrm{~mm}(200 \times 200$ DPI) 


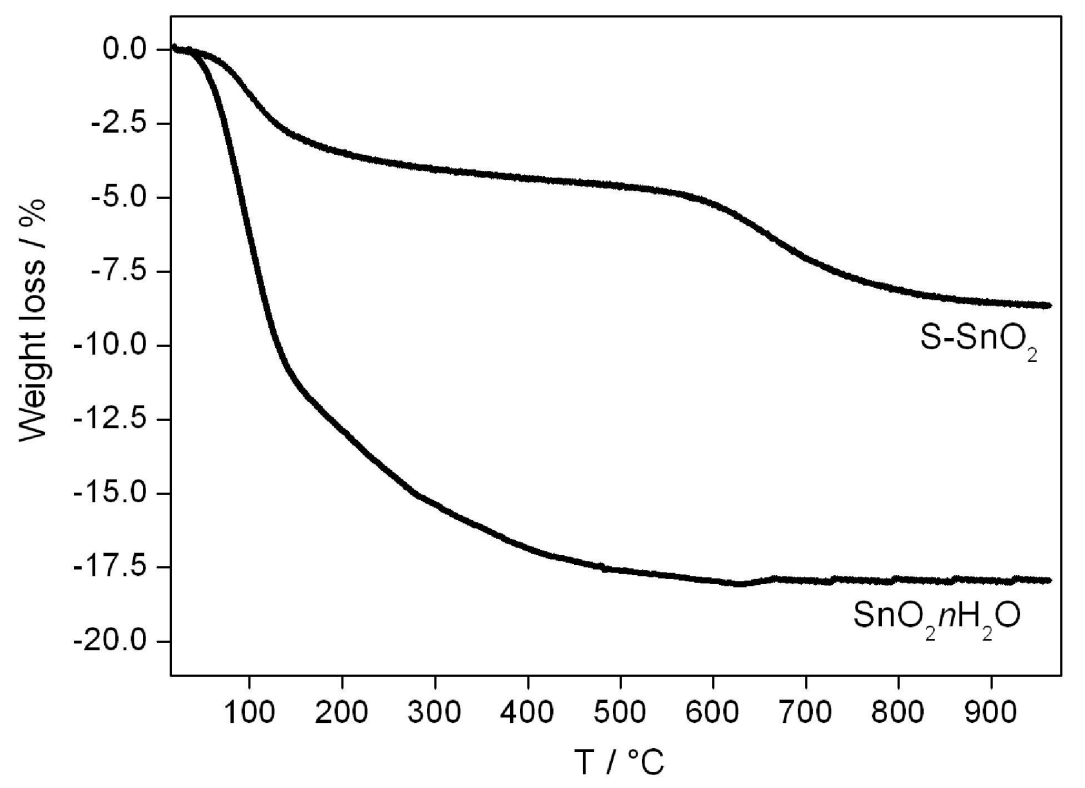

Fig. 4 TG profiles of $\mathrm{SnO} \bullet \bullet \mathrm{nH} 2 \mathrm{O}$ and $\mathrm{S}-\mathrm{SnO} 2$ powders.

Fig. 5 Proton conductivity values of unfilled Nafion and composite membranes at $100^{\circ} \mathrm{C}$ and $110^{\circ} \mathrm{C}$ $(\mathrm{RH}=100 \%)$.

$297 \times 209 \mathrm{~mm}(200 \times 200$ DPI $)$ 
Fig. 5 Proton conductivity values of unfilled Nafion and composite membranes at $100^{\circ} \mathrm{C}$ and $110^{\circ} \mathrm{C}$ ( $\mathrm{RH}=100 \%$ ).

$297 \times 209 \mathrm{~mm}(200 \times 200 \mathrm{DPI})$ 


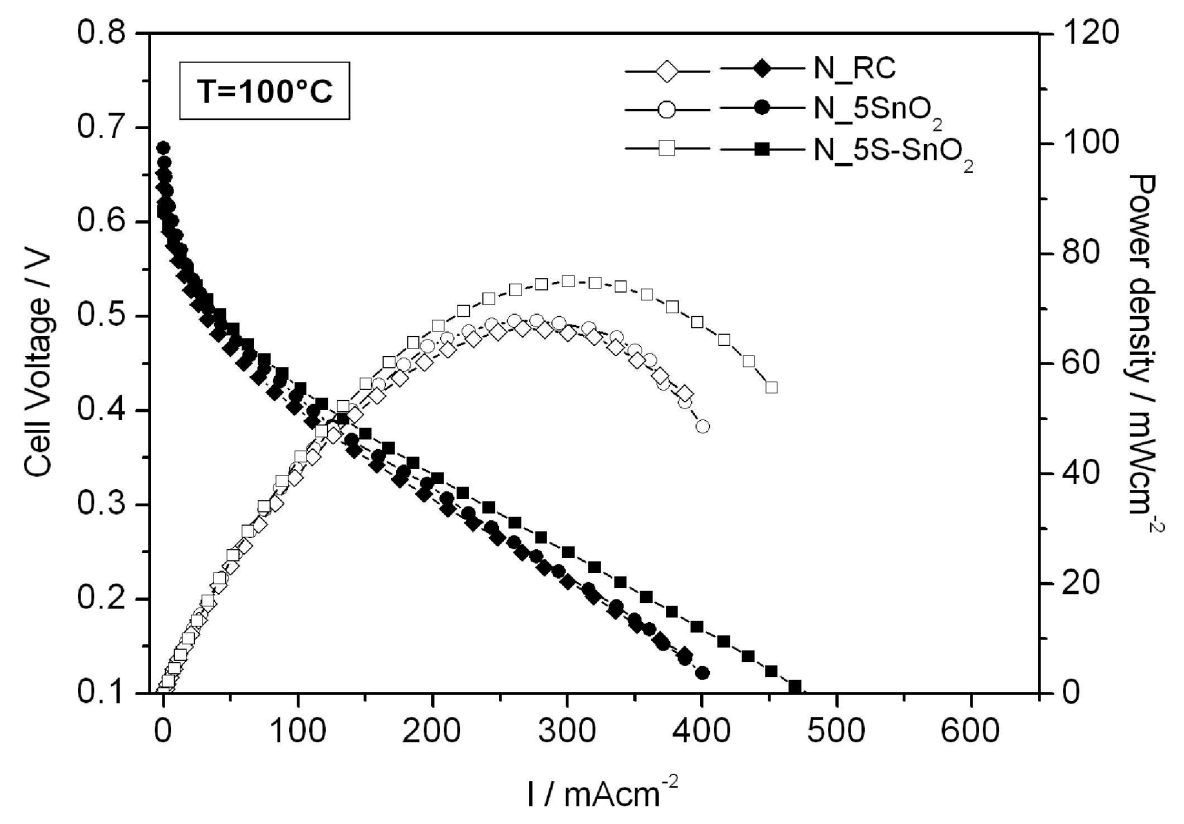

Fig. 6b Polarization and power density curves of unfilled Nafion and composite membranes at (a) $\mathrm{T}=100^{\circ} \mathrm{C}$ and (b) $\mathrm{T}=110^{\circ} \mathrm{C}$. Anode feed: $2 \mathrm{M}$ aqueous methanol, flow rate $2.5 \mathrm{mLmin}-1$, pressure 2 abs bar. Cathode feed: 02 flow rate $100 \mathrm{sccm}$, pressure 2 abs bar. 297x209mm (200 x 200 DPI) 
Fig. 6 Polarization and power density curves of unfilled Nafion and composite membranes at (a) $\mathrm{T}=100^{\circ} \mathrm{C}$ and (b) $\mathrm{T}=110^{\circ} \mathrm{C}$. Anode feed: $2 \mathrm{M}$ aqueous methanol, flow rate $2.5 \mathrm{mLmin}-1$, pressure 2 abs bar. Cathode feed: 02 flow rate $100 \mathrm{sccm}$, pressure 2 abs bar. 297x209mm (200 x 200 DPI) 
Fig. 7 Voltammetric curve for the oxidation of methanol permeating through the N_5SnO2 membrane exposed to a $2 \mathrm{M}$ methanol feed. $\mathrm{T}=80^{\circ} \mathrm{C}$. Inset: Limiting current density (Jlim) values of N_RC, N_5SnO2, and N_5S-SnO2 membranes $297 \times 209 \mathrm{~mm}(200 \times 200$ DPI $)$ 


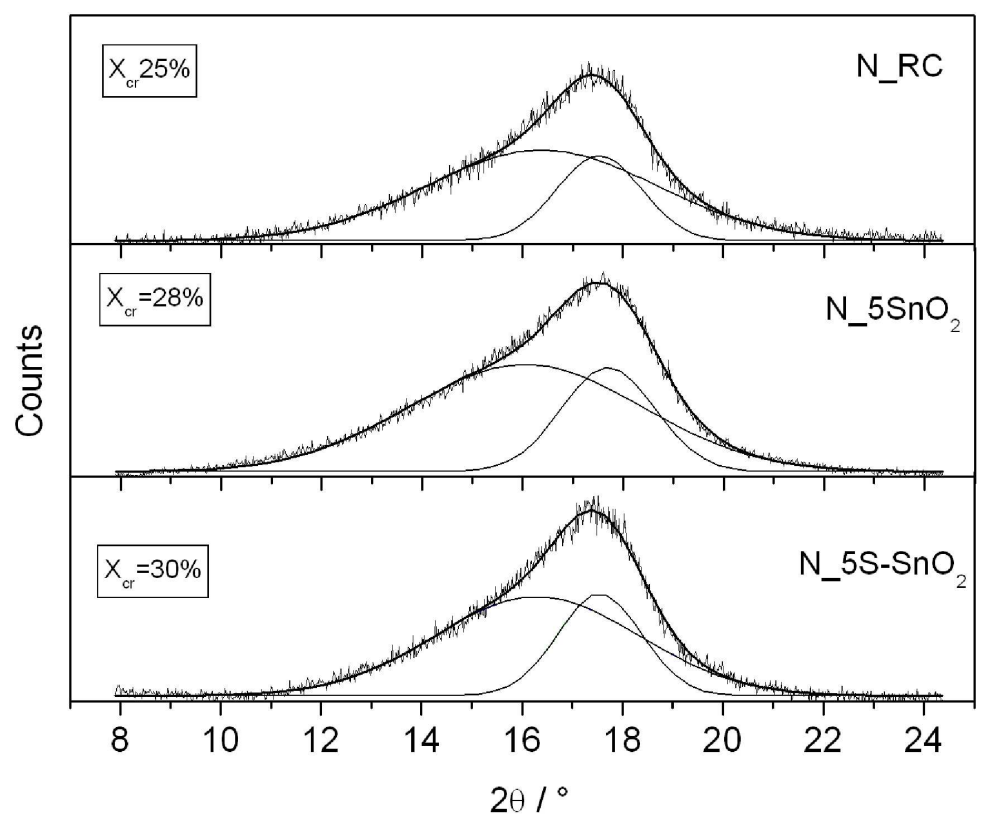

Fig. 8 XRD patterns of N_RC, N_5SnO2, and N_5S-SnO2 membranes. $297 \times 209 \mathrm{~mm}(200 \times 200$ DPI $)$ 
Fig. 9 Impedance spectra of MEAs made up with N_RC, N_5SnO2 and N_5S-SnO2 membranes as electrolytes, during DMFC functioning at $90^{\circ} \mathrm{C}, 100^{\circ} \mathrm{C}$ and $110^{\circ} \mathrm{C}$. Anode feed: $2 \mathrm{M}$ aqueous methanol. Cathode feed: 02 . $279 \times 215 \mathrm{~mm}(250 \times 250$ DPI $)$ 
Fig. 10 Charge transfer resistance, Rct (a) and mass transfer resistance, Rmass (b) as a function of temperature for MEAs made up with N_RC, N_5SnO2 and N_5S-SnO2 membranes as electrolytes. $297 \times 209 \mathrm{~mm}(200 \times 200 \mathrm{DPI})$ 
Fig. 11 Polarization and power density curves of the MEA prepared by brushing and containing N_5S-SnO2 membrane as electrolyte at (a) $\mathrm{T}=100^{\circ} \mathrm{C}$ and (b) $\mathrm{T}=110^{\circ} \mathrm{C}$. Anode feed: $2 \mathrm{M}$ aqueous methanol, flow rate $2.5 \mathrm{mLmin}-1$, pressure 2 abs bar. Cathode feed: 02 flow rate 100 sccm, pressure 2 abs bar. $297 \times 209 \mathrm{~mm}(200 \times 200$ DPI $)$ 
Fig.12 Impedance spectra of the MEA prepared by brushing and containing N_5S-SnO2 membrane as electrolyte, during DMFC functioning at $90^{\circ} \mathrm{C}, 100^{\circ} \mathrm{C}$ and $110^{\circ} \mathrm{C}$. Anode feed: $2 \mathrm{M}$ aqueous methanol. Cathode feed: 02. Inset: Charge transfer resistance, Rct (a) and mass transfer resistance, Rmass (b) as a function of temperature. $279 \times 215 \mathrm{~mm}(200 \times 200 \mathrm{DPI})$ 